\title{
Sodium-Hydrogen Exchange and Glucose Transport in Renal Microvillus Membrane Vesicles from Rats with Diabetes Mellitus
}

\author{
Raymond C. Harris, Barry M. Brenner, and Julian L. Seifter \\ Laboratory of Kidney and Electrolyte Physiology and Department of Medicine, Brigham and Women's Hospital; and \\ Harvard Medical School, Boston, Massachusetts 02115
}

\begin{abstract}
Diabetes mellitus is associated with important changes in renal hemodynamics and transport function. Disturbances in solute transport have also been characterized in nonrenal tissues during hyperglycemia and insulinopenia. The purpose of this study was to determine if diabetes is associated with adaptive changes in function of the brush-border membrane of the proximal tubule. We studied $\mathrm{Na}^{+}$and glucose transport in rat microvillus membrane vesicles isolated from the renal cortex of streptozotocininduced and BB/W autoimmune diabetic rats. Untreated diabetes was associated with an increase in pH-stimulated total and amiloride-sensitive ${ }^{22} \mathrm{Na}^{+}$uptake into vesicles. Insulin treatment returned vesicle ${ }^{22} \mathrm{Na}^{+}$uptake to control levels. The increased $\mathrm{Na}^{+} /$ $\mathrm{H}^{+}$exchange was shown to be a result of increased net renal acid production rather than a specific response to insulinopenia because treatment with $\mathrm{NaHCO}_{3}$ also returned ${ }^{22} \mathrm{Na}^{+}$uptake to control levels. On the other hand, $\mathrm{Na}^{+}$-glucose cotransport, which was depressed in vesicles from untreated diabetics, returned to control levels with insulin but not $\mathrm{NaHCO}_{3}$ administration. This decreased $\mathrm{Na}^{+}$-glucose cotransport was not secondary to reduction in transport sites in untreated diabetics. These results show that in diabetes mellitus, increased $\mathrm{Na}^{+} / \mathrm{H}^{+}$exchange activity is not the direct result of insulinopenia. However, the diabetic state appears to alter the functioning of the luminal $\mathrm{Na}^{+}$-glucose cotransporter.
\end{abstract}

\section{Introduction}

Insulin-dependent diabetes mellitus induces a wide range of pathophysiological alterations. Insulin serves as a modulator of many physiologic processes, and many of the abnormalities seen in diabetes result from abnormal metabolic function that is a direct result of the insulin deficiency. Other disturbances may be the result of the diabetic milieu and may be only indirectly caused by a decrease in circulating insulin.

In poorly controlled diabetes mellitus, with hyperglycemia and insulinopenia, a number of renal changes have been noted. These include increased glomerular filtration rate and renal blood flow (1), generalized renal hypertrophy (2), basement membrane thickening and glomerular damage (3), increased ammoniagenesis and gluconeogenesis (4), and decreased absolute reabsorption of fluid and $\mathrm{Na}^{+}(5)$. Insulin has been reported to influence renal

Portions of this work have been published in abstract form, 1983. Clin. Res. 31:699. Address reprint requests to Dr. Seifter.

Received for publication 31 May 1985 and in revised form 7 November 1985.

J. Clin. Invest.

(c) The American Society for Clinical Investigation, Inc.

0021-9738/86/03/0724/10 \$1.00

Volume 77, March 1986, 724-733 handling of $\mathrm{Na}^{+}$and solutes by increasing reabsorption of $\mathrm{Na}^{+}$ in distal nephron segments and increasing phosphate reabsorption in proximal segments $(6,7)$. In adipose tissue, insulin increases the concentration of plasma membrane glucose carriers (8).

The purpose of the present study was to determine the effects of diabetes mellitus on transport of glucose and $\mathrm{Na}^{+}$in isolated rat renal microvillus membrane vesicles. The results indicate that the increased net acid production of untreated diabetes mellitus, whether associated with systemic acidemia or not, is accompanied by an increase in $\mathrm{Na}^{+} / \mathrm{H}^{+}$exchange activity in luminal membranes. Furthermore, $\mathrm{Na}^{+}$-dependent glucose transport is decreased in membrane vesicles derived from diabetic animals. These results suggest intrinsic changes in proximal tubule transport function in diabetes.

\section{Methods}

Animals. Two experimental models of diabetes mellitus were employed in these studies. In the first model, insulin-dependent diabetes was induced in male Sprague Dawley rats (Charles River Breeding Laboratories, Wilminton, MA) by a single intravenous injection of streptozotocin $(60 \mathrm{mg}$ / $\mathrm{kg}$ ). We used only animals that demonstrated hyperglycemia and glycosuria within $48 \mathrm{~h}$ after injection. Animals were studied 8-14 d after administration of streptozotocin. An insulin-treated subgroup received a daily subcutaneous injection of $2.5 \mathrm{U}$ ultralente insulin (NOVO; Copenhagen, Denmark) in the afternoon. Another subgroup received drinking water with $75 \mathrm{meq} / \mathrm{liter} \mathrm{NaHCO}_{3}$ added, in an attempt to correct the increased endogenous acid production associated with diabetes. As a control for this group, some diabetic rats received equivalent $\mathrm{Na}^{+}$as $\mathrm{NaCl}$ in the drinking water.

The second model of diabetes employed was the $\mathrm{BB} / \mathrm{W}$ autoimmune model of diabetes (9). Male rats were obtained from the breeding colony at University of Massachusetts Medical School, Worcester, MA. The animals studied either manifested insulin-dependent diabetes or were age-matched BB/W rats without evidence of diabetes. Insulin-treated animals received a single afternoon injection of protamine-zinc insulin (PZI; Eli Lilly and Co., Indianapolis, IN), calculated to prevent ketosis. Bicarbonate-treated animals received drinking water supplemented with $250 \mathrm{meq} /$ liter $\mathrm{NaHCO}_{3}$.

All animals were fed standard $24 \%$ protein rat chow (Ralston Purina Co., St. Louis, MO). Blood gases and serum for glucose determination were obtained on the morning of study. Qualitative serum ketone determination was performed by measurement with ketostix (Miles Laboratories, Inc., Elkhart, IN). Net acid excretion rates were determined for 24-h urine collections (10).

Vesicle preparation. Animals were killed by decapitation or cervical dislocation and the kidneys were promptly removed and weighed. Renal cortical microvillus membrane vesicles were prepared by the $\mathbf{M g}^{++}$aggregation and differential centrifugation method of Booth and Kenny (11) and Aronson (12). For studies of $\left[{ }^{3} \mathrm{H}\right] \mathrm{D}$-glucose uptake and $\left[{ }^{3} \mathrm{H}\right]$ phlorizin binding, the microvillus membrane vesicles were prepared and experiments were performed in a buffered isotonic solution containing $300 \mathrm{mM}$ mannitol, $16 \mathrm{mM}$ Hepes, and $10 \mathrm{mM}$ Tris, pH 7.50 . The studies of $\mathrm{Na}^{+} / \mathrm{H}^{+}$exchange were performed using microvillus membrane vesicles prepared in a highly buffered isotonic solution, con- 
sisting of $270 \mathrm{mM}$ mannitol, $40 \mathrm{mM}$ Hepes titrated to $\mathrm{pH} 7.50$ with $\mathrm{KOH}$. An intravesicular $\mathrm{pH}$ of 6.10 was obtained by preequilibration of suspensions of the membrane vesicles diluted $1: 1$ with a solution con-

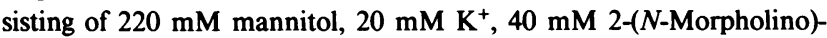
ethane sulfonic acid (MES), $40 \mathrm{mM}$ Hepes. The brush border membrane marker enzyme, alkaline phosphatase, was assayed using $p$-nitrophenyl phosphate as substrate (Sigma bulletin \# 104, Sigma Chemical Co., St. Louis, $\mathrm{MO}$ ) and $\mathrm{Na}^{+}-\mathrm{K}^{+}$ATPase, a marker of basolateral membranes, was assayed as ouabain-sensitive $\mathrm{K}^{+}$phosphatase (13). The homogenate specific activities for alkaline phosphatase and ouabain-sensitive $\mathrm{K}^{+}$ phosphatase were comparable in the membrane preparations from the different experimental groups. As shown in Table I, enzyme specific activity and purification of brush border membrane vesicles in streptozotocin treated diabetes was comparable to control values for Sprague Dawley rats. The activities and enrichment of brush border membrane vesicles in the $\mathrm{BB} / \mathrm{W}$ diabetic rats was also comparable to control values for BB/W animals. Protein was determined by the method of Lowry et al. (14) or by Bradford (15).

Transport. Timed uptake of radiolabeled solutes at $20^{\circ} \mathrm{C}$ was assayed by Millipore rapid filtration methods (Millipore Corp., Bedford, MA) (16). Timed incubations were terminated by the addition of $4 \mathrm{ml}$ of an ice cold $\mathrm{MgSO}_{4}$ solution and then filtered immediately through a prewetted 0.65-micron filter (DAWP; Millipore Corp.). The filter was washed with an additional $12 \mathrm{ml}$ of the $\mathrm{MgSO}_{4}$ solution. Filters were then dissolved in $4.5 \mathrm{ml}$ of Aquasol (New England Nuclear, Boston, MA) and radioactivity was determined by liquid scintillation spectrometry. Nonspecific retention of radioactivity to the filters was subtracted from total counts of the sample. All incubations were performed in triplicate using fresh membrane preparations. Tracer $\left[{ }^{3} \mathrm{H}\right] \mathrm{D}$-glucose uptakes were performed in the presence of $0.35 \mu \mathrm{M}\left[{ }^{3} \mathrm{H}\right] \mathrm{D}$-glucose. Uptake of $\left[{ }^{3} \mathrm{H}\right]$ phlorizin was assayed by the method of Aronson (12). $10 \mu \mathrm{l}$ of microvillus membrane suspension was incubated at $20^{\circ} \mathrm{C}$ with $40 \mu \mathrm{l}$ of a mannitol solution buffered with $10 \mathrm{mM}$ Tris, $16 \mathrm{mM}$ Hepes, $\mathrm{pH} 7.50$, containing $50 \mathrm{mM} \mathrm{Na}_{2} \mathrm{SO}_{4}$ and $\left[{ }^{3} \mathrm{H}\right]$ phlorizin concentrations of $0.05-$ $100 \mu \mathrm{M}\left(4 \times 10^{4} \mathrm{cpm}\right)$. Preliminary experiments revealed that equilibrium binding of $0.05 \mu \mathrm{M}$ phlorizin in the presence of $50 \mathrm{mM} \mathrm{Na}_{2} \mathrm{SO}_{4}$ occurred between 10 and $30 \mathrm{~min}$ and remained stable for at least $60 \mathrm{~min}$. Therefore, incubations for binding assays were performed for $\mathbf{4 0 ~} \mathrm{min}$. Incubations were terminated by addition of an ice cold solution containing $150 \mathrm{mM}$ $\mathrm{NaCl}, 10 \mathrm{mM} \mathrm{MgSO}_{4}, 1 \mathrm{mM}$ Tris, $1 \mathrm{mM}$ Hepes, $\mathrm{pH}$ 7.50. The rapid filtration process described above was employed.

Statistics. Results are expressed as mean \pm SEM for at least three separate experiments on different membrane preparations. Student's unpaired $t$ test was used. In multiple group comparisons, one way analysis of variance and the Bonferroni $t$ test were employed.

Materials. ${ }^{22} \mathrm{Na}^{+},\left[{ }^{3} \mathrm{H}\right] \mathrm{D}$-glucose $(31 \mathrm{Ci} / \mathrm{mmol}),\left[{ }^{3} \mathrm{H}\right] \mathrm{L}$-alanine $(108$ $\mathrm{Ci} / \mathrm{mmol})$, and $\left[{ }^{3} \mathrm{H}\right]$ phlorizin $(56 \mathrm{Ci} / \mathrm{mmol})$ were obtained from New England Nuclear. Amiloride was a gift of Merck, Sharp, and Dohme, Inc. (West Point, PA).

\section{Results}

In early (7-14 d) streptozotocin-induced diabetes, animals that were not treated with insulin experienced weight loss and profound hyperglycemia (Table II). Treatment with the ultralente insulin preparation significantly reduced the blood glucose levels ( $474 \pm 24$ vs. $186 \pm 24 \mathrm{mg} / \mathrm{dl}, P<0.005$ ), although not completely to control. In addition, insulin treatment prevented the weight loss noted in the untreated diabetics. Untreated diabetic rats developed significant renal hypertrophy. Whole kidney weight increased from an average control value of $3.14 \pm 0.06 \mathrm{~g}$ to $3.69 \pm 0.11(P<0.005)$. Kidney weight as a percentage of body weight was also increased in diabetics $(1.07 \pm 0.03 \%$ vs. $0.82 \pm 0.02$; $P<0.005)$. Insulin-treated rats sustained smaller but significant increases in whole kidney weight; values corrected for body weight were slightly greater than control values $(0.87 \pm 0.02 \%$ vs. $0.82 \pm 0.02$ ). $\mathrm{NaHCO}_{3}$-treated diabetic rats underwent less gain of renal weight than untreated diabetics $(3.35 \pm 0.12 \mathrm{~g}$ vs. $3.69 \pm 0.11, P<0.05)$. Although untreated diabetic rats developed significant ketonemia, metabolic acidosis was not present $(\mathrm{pH}$ $7.43 \pm 0.02$ in control vs. $7.42 \pm 0.03$ in diabetic rats). Urinary excretion rates of net acid were increased in the streptozotocintreated animals $(4.90 \pm 0.9 \mathrm{meq} / \mathrm{dl}$ vs. $1.50 \pm 0.38, P<0.005)$.

Table III provides similar data for the $\mathrm{BB} / \mathrm{W}$ rats. These rats

Table I. Enzyme Activity and Purification of Brush Border Membrane Vesicle Preparations of the Experimental Groups

\begin{tabular}{|c|c|c|c|}
\hline & \multirow[b]{2}{*}{ Control } & \multicolumn{2}{|c|}{ Streptozotocin-induced diabetes } \\
\hline & & No treatment & + insulin \\
\hline \multicolumn{4}{|l|}{ Alkaline phosphatase $(n)$} \\
\hline $\begin{array}{l}\text { Specific activity ( } \mu \mathrm{mol} p N P P / m g \text { protein per } \mathrm{min} \text { ) } \\
\text { Enrichment }\end{array}$ & $\left.\begin{array}{l}0.52 \pm 0.06 \\
10.1 \pm 0.8\end{array}\right\}(14)$ & $\left.\begin{array}{c}0.63 \pm 0.07 \\
9.4 \pm 0.9\end{array}\right\}(14)$ & $\left.\begin{array}{l}0.58 \pm 0.06 \\
10.5 \pm 0.6\end{array}\right\}(8)$ \\
\hline \multicolumn{4}{|l|}{ Ouabain-sensitive ATPase $(n)$} \\
\hline \multirow[t]{2}{*}{$\begin{array}{l}\text { Specific activity ( } \mu \mathrm{mol} p N P P / m g \text { per } \mathrm{min} \text { ) } \\
\text { Enrichment }\end{array}$} & $\left.\begin{array}{c}0.0039 \pm 0.0007 \\
0.66 \pm 0.08\end{array}\right\}(14)$ & $\left.\begin{array}{c}0.0024 \pm 0.0004 \\
0.50 \pm 0.05 \\
\mathrm{BB} / \mathrm{W}\end{array}\right\}(14)$ & $\left.\begin{array}{c}0.0054 \pm 0.0008 \\
0.71 \pm 0.13\end{array}\right\}(8)$ \\
\hline & Control & No treatment & + insulin \\
\hline \multicolumn{4}{|l|}{ Alkaline phosphatase $(n)$} \\
\hline $\begin{array}{l}\text { Specific activity ( } \mu \mathrm{mol} p N P P / m g \text { per min) } \\
\text { Enrichment }\end{array}$ & $\left.\begin{array}{c}0.30 \pm 0.02 \\
7.3 \pm 0.3\end{array}\right\}(9)$ & $\left.\begin{array}{c}0.30 \pm 0.02 \\
8.1 \pm 0.8\end{array}\right\}(7)$ & $\left.\begin{array}{c}0.30 \pm 0.03 \\
7.9 \pm 0.8\end{array}\right\}(9)$ \\
\hline \multicolumn{4}{|l|}{ Ouabain-sensitive ATPase ( $n$ ) } \\
\hline $\begin{array}{l}\text { Specific activity ( } \mu \mathrm{mol} \mathrm{pNPP} / \mathrm{mg} \text { per } \mathrm{min} \text { ) } \\
\text { Enrichment }\end{array}$ & $\left.\begin{array}{c}0.0031 \pm 0.0010 \\
0.52 \pm 0.07\end{array}\right\}(9)$ & $\left.\begin{array}{c}0.0030 \pm 0.0008 \\
0.57 \pm 0.03\end{array}\right\}(7)$ & $\left.\begin{array}{c}0.0023 \pm 0.0007 \\
0.38 \pm 0.09\end{array}\right\}(9)$ \\
\hline
\end{tabular}

Specific activity in vesicle preparation is expressed as $\mu \mathrm{mol} p$-nitrophenyl phosphate (pNPP) hydrolyzed/mg membrane protein per min at $20^{\circ} \mathrm{C}$ for alkaline phosphatase and $37^{\circ} \mathrm{C}$ for ATPase. Enrichment factor refers to activity in vesicle preparation compared with activity in the whole cortex. 
Table II. Physiologic Parameters in Streptozotocin-induced Diabetes Mellitus

\begin{tabular}{|c|c|c|c|c|}
\hline & \multirow[b]{2}{*}{ Control } & \multicolumn{3}{|l|}{ Diabetes } \\
\hline & & No treatment & + insulin & $+\mathrm{NaHCO}_{3}$ \\
\hline $\begin{array}{l}\text { Body weight } \\
(g)\end{array}$ & $\begin{array}{l}386 \pm 6 \\
(30)\end{array}$ & $\begin{array}{l}343 \pm 7 \ddagger \\
(25)\end{array}$ & $\begin{array}{l}391 \pm 12 \\
(30)\end{array}$ & $\begin{array}{l}353 \pm 13 \\
(14)\end{array}$ \\
\hline $\begin{array}{l}\text { Kidney weight } \\
(g)\end{array}$ & $\begin{array}{l}3.14 \pm 0.06 \\
(30)\end{array}$ & $\begin{array}{l}3.69 \pm 0.11 \ddagger \\
(25)\end{array}$ & $\begin{array}{l}3.51 \pm 0.08 \ddagger \\
(30)\end{array}$ & $\begin{array}{l}3.34 \pm 0.12 \ddagger \\
(14)\end{array}$ \\
\hline $\begin{array}{l}\text { Kidney weight, } \\
\text { \% Body weight }\end{array}$ & $0.82 \pm 0.02$ & $1.07 \pm 0.03 \ddagger$ & $0.87 \pm 0.02^{*}$ & $0.96 \pm 0.03 \ddagger$ \\
\hline $\begin{array}{l}\text { Blood } \\
\text { Glucose } \\
\qquad(m g / d l)\end{array}$ & $\begin{array}{l}131 \pm 6 \\
(7)\end{array}$ & $\begin{array}{l}474 \pm 24 \ddagger \\
(25)\end{array}$ & $\begin{array}{l}186 \pm 24 \\
(30)\end{array}$ & $\begin{array}{l}364 \pm 70^{*} \\
(14)\end{array}$ \\
\hline pH & $\begin{array}{l}7.43 \pm .02 \\
(7)\end{array}$ & $\begin{array}{l}7.42 \pm .03 \\
(8)\end{array}$ & $\begin{array}{l}7.43 \pm .01 \\
(6)\end{array}$ & $\begin{array}{l}7.38 \pm .03 \\
(9)\end{array}$ \\
\hline $\begin{array}{l}\mathrm{pCO}_{2} \\
(m m H g)\end{array}$ & $39 \pm 3$ & $36 \pm 3$ & $42 \pm 2$ & $48 \pm 5$ \\
\hline $\begin{array}{l}\mathrm{HCO}_{3} \\
\quad(m E q / \text { liter })\end{array}$ & $25 \pm 2$ & $24 \pm 2$ & $28 \pm 1$ & $28 \pm 2$ \\
\hline $\begin{array}{l}\text { Ketones } \\
(m g / d l)\end{array}$ & $\begin{array}{l}0 \pm 0 \\
(11)\end{array}$ & $\begin{array}{l}12 \pm 3 \ddagger \\
(10)\end{array}$ & (4) $0 \pm 0$ & ${ }_{(5)}^{14 \pm 5 \ddagger}$ \\
\hline
\end{tabular}

Body weight, kidney weight, and glucose concentrations were determined for all diabetic animals used in transport studies. Arterial blood gases, and ketone measurements were performed on a subset of control and diabetic rats used in vesicle studies. The number of animals, $n$, is indicated in parenthesis.

$* P<0.05$ compared with control.

$\ddagger P<0.005$ compared with control. were diabetic for $79 \pm 14 \mathrm{~d}$, a significantly longer period than were the streptozotocin-treated animals. They were maintained on insulin after the onset of hyperglycemia. Insulin was withheld from the animals in the untreated and bicarbonate-treated groups for 48-72 $\mathrm{h}$ before sacrifice. These two subgroups both experienced significant weight loss (untreated, $14 \pm 2 \%$; bicarbonatetreated, $9 \pm 2 \%$ ). Kidney weights in the untreated and bicarbonatetreated groups were not significantly different from control. However, note that the animals in these two subgroups were smaller to begin with than the animals in the control and insulintreated groups. Thus, kidney weight corrected for body weight was markedly increased in all hyperglycemic animals. The daily insulin treatment was insufficient to control blood glucose concentrations. The average values were $130 \pm 6 \mathrm{mg} / \mathrm{dl}$ in control; $324 \pm 9$ in the untreated diabetic, and $360 \pm 30$ in the insulintreated animals. Withholding insulin resulted in a profound aci-

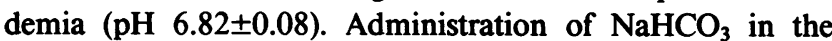
drinking water corrected the acidemia $(\mathrm{pH} \mathrm{7.41 \pm 0.02)}$ as did insulin treatment $(\mathrm{pH} 7.43 \pm 0.01)$.

$\mathrm{Na}^{+}$transport. Previous studies have revealed that in the presence of an inside acid $\mathrm{pH}$ gradient, the majority of $1 \mathrm{mM}$ ${ }^{22} \mathrm{Na}^{+}$uptake into brush border membrane vesicles is mediated by $\mathrm{Na}^{+} / \mathrm{H}^{+}$exchange (17). As indicated in Table IV, in the streptozotocin-induced diabetics, 5- and $10-\mathrm{s}^{22} \mathrm{Na}^{+}$influx into vesicles isolated from untreated animals was significantly greater than for control rats $(5 \mathrm{~s}, 1.78 \pm 0.10 \mathrm{nmol} / \mathrm{mg}$ protein vs. $1.31 \pm 0.06$, $P<0.005 ; 10$ s, $2.70 \pm 0.11$ vs. $1.94 \pm 0.08, P<0.005)$. To determine the component of $\mathrm{Na}^{+}$flux occurring via $\mathrm{Na}^{+} / \mathrm{H}^{+}$exchange, the effect of the pyrazine diuretic amiloride was tested. In microvillus membrane vesicles, $1 \mathrm{mM}$ amiloride inhibits electroneutral $\mathrm{Na}^{+} / \mathrm{H}^{+}$exchange (18). As shown in Fig. 1, the ${ }^{22} \mathrm{Na}^{+}$flux inhibitable by amiloride was significantly greater in

Table III. Physiologic Parameters in BB/W Rats

\begin{tabular}{|c|c|c|c|c|}
\hline & \multirow[b]{2}{*}{ Control } & \multicolumn{3}{|l|}{ Diabetes } \\
\hline & & No treatment & + insulin & $+\mathrm{NaHCO}_{3}$ \\
\hline Body weight $(g)$ & $\begin{array}{l}383 \pm 25 \\
(6)\end{array}$ & $\begin{array}{l}266 \pm 6^{*} \\
(4)\end{array}$ & $\begin{array}{l}374 \pm 26 \\
(6)\end{array}$ & $\begin{array}{l}247 \pm 24^{*} \\
(3)\end{array}$ \\
\hline Kidney weight $(g)$ & $\begin{array}{l}2.49 \pm 0.17 \\
(6)\end{array}$ & $\begin{array}{l}2.70 \pm 0.07^{*} \\
(4)\end{array}$ & $\begin{array}{l}2.87 \pm 0.16^{*} \\
(6)\end{array}$ & $\begin{array}{l}2.41 \pm 0.28 \\
(3)\end{array}$ \\
\hline $\begin{array}{l}\text { Kidney weight } \\
\text { \% Body weight }\end{array}$ & $0.65 \pm 0.02$ & $1.01 \pm 0.01 \ddagger$ & $0.78 \pm 0.04$ & $0.97 \pm 0.03 \ddagger$ \\
\hline $\begin{array}{l}\text { Blood } \\
\text { Glucose }(m g / d l)\end{array}$ & $\begin{array}{l}130 \pm 6 \\
(6)\end{array}$ & $\begin{array}{l}324 \pm 9 \ddagger \\
(4)\end{array}$ & $\begin{array}{l}360 \pm 30 \ddagger \\
(6)\end{array}$ & $\begin{array}{l}324 \pm 35 \ddagger \\
\text { (3) }\end{array}$ \\
\hline pH & $\begin{array}{l}7.45 \pm 0.05 \\
(6)\end{array}$ & $\begin{array}{l}6.82 \pm 0.08 \ddagger \\
(4)\end{array}$ & $\begin{array}{l}7.43 \pm 0.01 \\
(6)\end{array}$ & $\begin{array}{l}7.41 \pm 0.02 \\
(3)\end{array}$ \\
\hline $\mathrm{pCO}_{2}(\mathrm{mmHg})$ & $40 \pm 7$ & $18 \pm 3 \ddagger$ & $40 \pm 1$ & $50 \pm 4$ \\
\hline $\mathrm{HCO}_{3}(m E q /$ liter $)$ & $29 \pm 2$ & $4 \pm 1 \mp$ & $26 \pm 1$ & $32 \pm 3$ \\
\hline Ketones $(m g / d l)$ & (3) $0 \pm 0$ & ${ }^{37}{ }^{37 \pm 14 \ddagger}$ & $\begin{array}{l}3.5 \pm 3 \\
(3)\end{array}$ & (3) \\
\hline
\end{tabular}

Body weight, kidney weight, glucose concentrations, and arterial blood gases were determined for all control and diabetic rats used in vesicle studies. Ketones were measured in a subset of these animals. The number of animals in each group, $n$, is given in parenthesis. ${ }^{*} P<0.05$ compared with control. $¥ P<0.005$ compared with control. 
Table IV. $1 \mathrm{mM}^{22} \mathrm{Na}^{+}$Uptake into Renal Microvillus Membrane Vesicles

\begin{tabular}{|c|c|c|c|c|c|}
\hline \multirow[b]{2}{*}{ Time } & \multirow[b]{2}{*}{ Control } & \multicolumn{4}{|c|}{ Streptozotocin-induced diabetes } \\
\hline & & No treatment & + insulin & $+\mathrm{NaHCO}_{3}$ & $+\mathrm{NaCl}$ \\
\hline $\begin{array}{l}5 \mathrm{~s} \\
(n)\end{array}$ & $\begin{array}{l}1.31 \pm 0.06 \\
(11)\end{array}$ & $\begin{array}{l}1.78 \pm 0.10^{*} \\
(7)\end{array}$ & - & $\begin{array}{l}1.40 \pm 0.12 \\
(5)\end{array}$ & $\begin{array}{l}1.77 \pm 0.12^{*} \\
(5)\end{array}$ \\
\hline $10 \mathrm{~s}$ & $\begin{array}{l}1.94 \pm 0.08 \\
(14)\end{array}$ & $\begin{array}{l}2.70 \pm 0.11^{*} \\
(10)\end{array}$ & $\begin{array}{l}2.10 \pm 0.02 \\
(4)\end{array}$ & $\begin{array}{l}2.09 \pm 0.14 \\
(5)\end{array}$ & $\begin{array}{l}2.64 \pm 0.16^{*} \\
(5)\end{array}$ \\
\hline $2 \mathrm{~h}$ & $\begin{array}{l}2.53 \pm 0.09 \\
(14)\end{array}$ & $\begin{array}{l}2.98 \pm 0.14 \\
(10)\end{array}$ & $\begin{array}{l}2.50 \pm 0.19 \\
(4)\end{array}$ & $\begin{array}{l}2.64 \pm 0.22 \\
(5)\end{array}$ & $\begin{array}{l}3.06 \pm 0.23 \\
(5)\end{array}$ \\
\hline \multicolumn{6}{|c|}{ +1 mM Amiloride } \\
\hline \multirow[t]{3}{*}{$10 \mathrm{~s}$} & $\begin{array}{l}0.35 \pm 0.02 \\
(5)\end{array}$ & $\begin{array}{l}0.41 \pm 0.06 \\
(10)\end{array}$ & $\begin{array}{l}0.38 \pm 0.17 \\
(3)\end{array}$ & $\begin{array}{l}0.26 \pm 0.04 \\
(5)\end{array}$ & $\begin{array}{l}0.31 \pm 0.04 \\
(5)\end{array}$ \\
\hline & & \multicolumn{3}{|c|}{ BB/W autoimmune diabetes } & \\
\hline & Control & No treatment & + insulin & $+\mathrm{NaHCO}_{3}$ & \\
\hline $\begin{array}{l}5 \mathrm{~s} \\
(n)\end{array}$ & $\begin{array}{l}0.77 \pm 0.07 \\
(4)\end{array}$ & $\begin{array}{l}1.48 \pm 0.06 \ddagger \\
\text { (3) }\end{array}$ & $\begin{array}{l}0.93 \pm 0.08 \\
(3)\end{array}$ & $\begin{array}{l}0.92 \pm 0.12 \\
(3)\end{array}$ & \\
\hline $10 \mathrm{~s}$ & $1.34 \pm 0.13$ & $2.05 \pm 0.14 \ddagger$ & $1.37 \pm 0.02$ & $1.43 \pm 0.06$ & \\
\hline $2 \mathrm{~h}$ & $2.20 \pm 0.10$ & $2.71 \pm 0.21$ & $2.35 \pm 0.16$ & $2.52 \pm 0.14$ & \\
\hline \multicolumn{6}{|c|}{ +1 mM Amiloride } \\
\hline $10 \mathrm{~s}$ & $0.25 \pm 0.11$ & $0.28 \pm 0.04$ & $0.19 \pm 0.06$ & $0.27 \pm 0.03$ & \\
\hline
\end{tabular}

Values given in $\mathrm{nmol} / \mathrm{mg}$ protein. Membrane vesicles were preincubated for $120 \mathrm{~min}$ to contain at equilibrium $224 \mathrm{mM}$ mannitol, $24 \mathrm{mM} \mathrm{K}+40$ mM Hepes, $40 \mathrm{mM} 2$ ( $N$-morpholino) ethane sulfonic acid (MES), pH 6.1. Influx of $1 \mathrm{mM}^{22} \mathrm{Na}^{+}$was measured after the addition of $10 \mu$ l of vesicle suspension to $40 \mu \mathrm{l}$ of a solution containing $264 \mathrm{mM}$ mannitol, $24 \mathrm{mM} \mathrm{K}^{+}, 40 \mathrm{mM}$ Hepes, pH 7.5 to give final external pH 7.2 .

* $P<0.005$ compared with control. $\ddagger P<0.05$ compared with control.

the untreated diabetics than in controls $(10 \mathrm{~s}, 2.29 \pm 0.12 \mathrm{nmol} /$ mg protein vs. $1.67 \pm 0.15, P<0.05)$. In addition, there were no differences in the amiloride insensitive ${ }^{22} \mathrm{Na}^{+}$flux in the untreated group compared with control (Table IV). In the insulin-treated group, total ${ }^{22} \mathrm{Na}^{+}$flux (10 s, $2.10 \pm 0.02 \mathrm{nmol} / \mathrm{mg}$ protein) and the amiloride sensitive component $(1.69 \pm 0.19)$ were not significantly different from control (Table IV and Fig. 1).

The streptozotocin-induced diabetic rat developed significant ketosis $(12 \pm 3 \mathrm{mg} / \mathrm{dl})$ without systemic metabolic acidosis $(\mathrm{pH}$

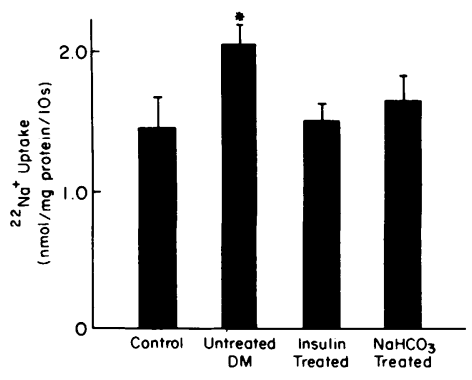

Figure $1 .{ }^{22} \mathrm{Na}^{+}$uptake in streptozotocin-induced diabetes mellitus inhibitable by $1 \mathrm{mM}$ amiloride. Vesicles were preincubated for 120 min to contain at equilibrium $224 \mathrm{mM}$ mannitol, 24 $\mathrm{mM} \mathrm{K}^{+}, 40 \mathrm{mM}$ Hepes, and $40 \mathrm{mM}$ MES, $\mathrm{pH} 6.1$. 10-s uptakes of $1 \mathrm{mM}$ ${ }^{22} \mathrm{NaCl}$ were performed after addition of $10 \mu \mathrm{l}$ of vesicle suspension to $40 \mu \mathrm{l}$ of external medium containing $1.25 \mathrm{mM}^{22} \mathrm{NaCl}, 264 \mathrm{mM}$ mannitol, $24 \mathrm{mM} \mathrm{K}^{+}, 40 \mathrm{mM}$ Hepes, pH 7.5, with or without amiloride (1 mM final concentration). Values represent the mean \pm SEM of from four to 10 experiments in each group. ${ }^{*} P<0.05$
$7.42 \pm 0.03)$. Insulin treatment abolished the ketosis and corrected the hyperglycemia. To determine if the stimulated $\mathrm{Na}^{+} / \mathrm{H}^{+}$exchange was due to hyperglycemia and/or insulinopenia or a manifestation of increased production of hydrogen during ketosis, a separate group of animals was given $\mathrm{NaHCO}_{3}$ in the drinking water. Each animal ingested at least $50 \mathrm{ml}$ water per day. As shown in Table II, bicarbonate treatment did not reduce hyperglycemia $(364 \pm 70 \mathrm{mg} / \mathrm{dl})$ or prevent ketosis. Arterial $\mathrm{pH}$ and plasma $\left[\mathrm{HCO}_{3}^{-}\right]$were not significantly different compared with control. As demonstrated in Table IV, bicarbonate treatment was associated with rates of $\mathrm{Na}^{+}$uptake similar to control values $(2.09 \pm 0.14 \mathrm{nmol} / \mathrm{mg}$ at $10 \mathrm{~s}$ vs. $1.94 \pm 0.08)$. As shown in Fig. 1, amiloride-sensitive $\mathrm{Na}^{+}$flux in the bicarbonate-treated group was also not significantly different from control (1.82 \pm 0.12 $\mathrm{nmol} / \mathrm{mg}$ per $10 \mathrm{~s}$ vs. $1.67 \pm 0.15)$. Since this last result occurred despite persistently elevated glucose concentrations and insulinopenia, a role for ketosis or acid load in stimulation of $\mathrm{Na}^{+} / \mathrm{H}^{+}$ exchange was suggested. Diabetic animals receiving $\mathrm{NaCl}$ instead of $\mathrm{NaHCO}_{3}$ in the drinking water did not differ in amiloridesensitive $\mathrm{Na}^{+}$flux when compared with the untreated diabetics $(2.34 \pm 0.16 \mathrm{nmol} / \mathrm{mg}$ per $10 \mathrm{~s}$ vs. $2.29 \pm 0.12)$.

$\mathrm{Na}^{+} / \mathrm{H}^{+}$exchange was also studied in the $\mathrm{BB} / \mathrm{W}$ autoimmune diabetic rat. Animals maintained on sufficient insulin to prevent ketonemia and metabolic acidosis (Table III) had ${ }^{22} \mathrm{Na}^{+}$uptake rates that were not different from control animals despite hyperglycemia. For example, as shown in Table IV, in the presence 


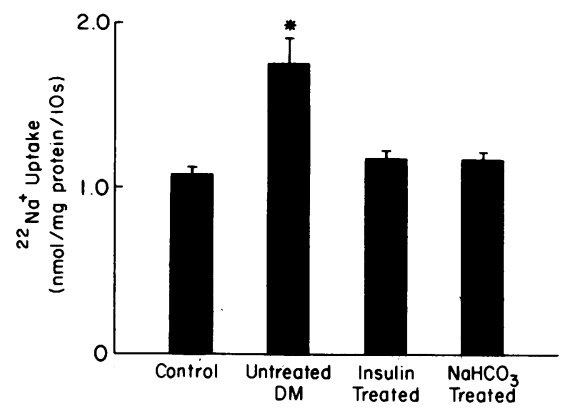

Figure $2 .{ }^{22} \mathrm{Na}^{+}$uptake in $\mathrm{BB} / \mathrm{W}$ autoimmune diabetes mellitus inhibitable by $1 \mathrm{mM}$ amiloride. Vesicles were prepared and transport assays performed as described for Fig. 1. Values represent the mean \pm SEM of from three to four experiments in each group. ${ }^{*} P<0.05$

of an inside acid pH gradient, $1 \mathrm{mM}^{22} \mathrm{Na}^{+}$uptake at $10 \mathrm{~s}$ was $1.37 \pm 0.02 \mathrm{nmol} / \mathrm{mg}$ protein in the insulin treated group vs. $1.34 \pm 0.13$ in control. On the other hand, withdrawal of insulin for 48-72 $\mathrm{h}$ resulted in a significant increase in the 10-s flux rate $(2.05 \pm 0.14 \mathrm{nmol} / \mathrm{mg}$ protein vs. $1.34 \pm 0.13 ; P<0.05)$. When these insulinopenic animals were simultaneously treated with sufficient $\mathrm{NaHCO}_{3}$ to suppress metabolic acidosis, the increases in $\mathrm{Na}^{+}$transport were also prevented (Tables III and IV). As shown in Fig. 2 untreated diabetics had increased amiloridesensitive $\mathrm{Na}^{+}$uptake, studied at $10 \mathrm{~s}(1.76 \pm 0.17 \mathrm{nmol} / \mathrm{mg}$ protein vs. $1.08 \pm 0.02$ in control; $P<0.05$ ). As with the streptozotocininduced diabetics, insulin treatment also prevented the increased amiloride-sensitive uptake $(1.18 \pm 0.14 \mathrm{nmol} / \mathrm{mg}$ protein vs. $1.08 \pm 0.02$ in control) as did $\mathrm{NaHCO}_{3}$ treatment (1.18 \pm 0.03$)$.

Glucose transport. $\mathrm{Na}^{+}$-glucose cotransport was also studied in brush border membrane vesicles in the streptozotocin induced model of early diabetes. As shown in Table V, glucose transport rates studied in the absence of $\mathrm{Na}^{+}\left(\mathrm{K}^{+}\right.$substitution) were not different in control and experimental groups. However, $\mathrm{Na}^{+}$dependent glucose uptakes, in the presence of an inwardly directed $\mathrm{Na}^{+}$gradient, were significantly decreased at each early time point in untreated diabetic animals. Thus, at $5 \mathrm{~s}$, glucose uptake averaged $0.70 \pm 0.09 \mathrm{pmol} / \mathrm{mg}$ protein in diabetics vs. $1.15 \pm 0.14$ in control $(P<0.005)$. Also shown in Table V, insulin treatment of diabetic animals completely prevented the decrease in glucose transport $(1.11 \pm 0.06 \mathrm{pmol} / \mathrm{mg}$ protein $/ 5 \mathrm{~s})$. The full time course of this effect is shown in Fig. 3.

A separate subgroup of diabetic rats were given 75 meq $\mathrm{NaHCO}_{3} /$ liter in their drinking water. In diabetics given $\mathrm{NaHCO}_{3}, \mathrm{Na}^{+}$glucose cotransport was still decreased in the presence of an inwardly directed $\mathrm{Na}^{+}$gradient, compared with simultaneously measured uptakes in a control group (Fig. $4 \mathrm{~A}$ ). Compared with controls, glucose transport was also decreased in vesicles from diabetic rats given daily low doses of insulin (0.5 U NOVO ultralente insulin subcutaneously) sufficient to prevent ketosis but not hyperglycemia and glycosuria. Since $\mathrm{Na}^{+} /$ $\mathrm{H}^{+}$exchange was increased in diabetic animals, it was possible that glucose flux was decreased due to greater dissipation of the $\mathrm{Na}^{+}$gradient, via $\mathrm{Na}^{+} / \mathrm{H}^{+}$exchange. Arguing against this interpretation are the results shown in Fig. $4 \mathrm{~A}$, in which $\mathrm{NaHCO}_{3}$ treatment in amounts sufficient to prevent increases in $\mathrm{Na}^{+} / \mathrm{H}^{+}$ exchange did not prevent decreases in glucose transport. Additional experiments were performed under $\mathrm{Na}^{+}$preequilibrated conditions in which $\mathrm{Na}^{+}$-dependent glucose transport can be evaluated in the absence of a $\mathrm{Na}^{+}$gradient. In results given in
Table V. Streptozotocin-induced Diabetes $\left[{ }^{3} H\right] D$-Glucose Uptake

\begin{tabular}{|c|c|c|c|}
\hline \multirow[b]{2}{*}{ Time } & \multirow[b]{2}{*}{ Control } & \multicolumn{2}{|l|}{ Diabetes } \\
\hline & & No treatment & + insulin \\
\hline \multicolumn{4}{|c|}{$\mathrm{KCl}_{\text {out }}=150 \mathrm{mM} ; \mathrm{KCl}_{\text {in }}=0 \mathrm{mM}$} \\
\hline $15 \mathrm{~s}$ & $0.11 \pm 0.01$ & $0.15 \pm 0.02$ & $0.11 \pm 0.03$ \\
\hline $2 \mathrm{~h}$ & $0.65 \pm 0.07$ & $0.57 \pm 0.05$ & $0.64 \pm 0.04$ \\
\hline$(n)$ & (5) & (6) & $(5)$ \\
\hline \multicolumn{4}{|c|}{$\mathrm{NaCl}_{\text {out }}=150 \mathrm{mM} ; \mathrm{NaCl}_{\text {in }}=0 \mathrm{mM}$} \\
\hline $5 \mathrm{~s}$ & $1.15 \pm 0.14$ & $0.70 \pm 0.09^{*}$ & $1.11 \pm 0.06$ \\
\hline $15 \mathrm{~s}$ & $2.95 \pm 0.20$ & $1.69 \pm 0.21 \ddagger$ & $2.98 \pm 0.22$ \\
\hline $60 \mathrm{~s}$ & $5.67 \pm 0.28$ & $3.46 \pm 0.41 \ddagger$ & $5.83 \pm 0.10$ \\
\hline $2 \mathrm{~h}$ & $0.72 \pm 0.05$ & $0.71 \pm 0.07$ & $0.75 \pm 0.02$ \\
\hline$(n)$ & (6) & (7) & $(5)$ \\
\hline \multicolumn{4}{|c|}{$\mathrm{NaCl}_{\text {out }}=\mathrm{NaCl}_{\text {in }}=80 \mathrm{mM}$} \\
\hline $15 \mathrm{~s}$ & $0.25 \pm 0.04$ & $0.20 \pm 0.02$ & $0.21 \pm 0.03$ \\
\hline $60 \mathrm{~s}$ & $0.37 \pm 0.06$ & $0.31 \pm 0.03$ & $0.32 \pm 0.02$ \\
\hline $2 \mathrm{~h}$ & $0.38 \pm 0.05$ & $0.34 \pm 0.05$ & $0.36 \pm 0.04$ \\
\hline$(n)$ & (8) & (4) & (4) \\
\hline
\end{tabular}

Values given in $\mathrm{pmol} / \mathrm{mg}$ protein. Membrane vesicles were prepared and assays performed as described for Fig. 3 .

$* P<0.05$.

$\ddagger P<0.005$.

Table $\mathrm{V}$, initial rates of $\mathrm{Na}^{+}$-dependent glucose uptake under the nongradient condition, $\mathrm{Na}_{\text {in }}^{+}=\mathrm{Na}_{\text {out }}^{+}=80 \mathrm{mM}$, revealed a statistically insignificant decrease in diabetic compared with control vesicles $(0.20 \pm 0.02 \mathrm{pmol} / \mathrm{mg}$ protein per $15 \mathrm{~s}$ vs. $0.25 \pm 0.04)$. It is also apparent from Table $\mathrm{V}$ that non- $\mathrm{Na}^{+}$-dependent transport might contribute importantly to total glucose uptake studied under the $\mathrm{Na}^{+}$preequilibrated condition, thereby possibly obscuring a significant decrease in transport in diabetic animals. To accentuate the component of $\mathrm{Na}^{+}$-dependent glucose transport under the nongradient condition, initial rates of glucose transport were determined at an increased ambient tem-

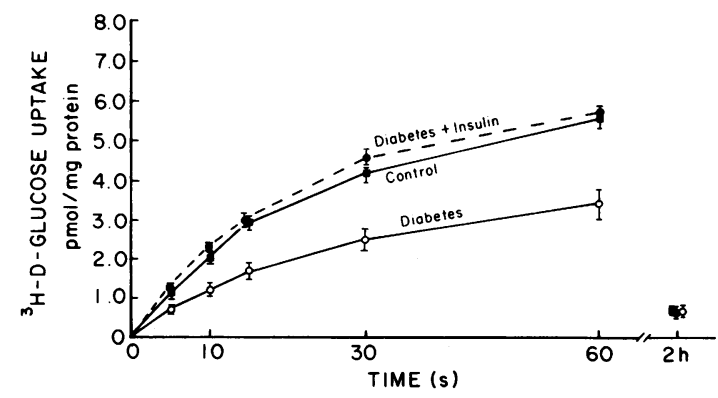

Figure 3. Time course of $\mathrm{Na}^{+}$gradient-dependent $\left[{ }^{3} \mathrm{H}\right] \mathrm{D}$-glucose uptake in streptozotocin-induced diabetes mellitus. Vesicles were prepared in $300 \mathrm{mM}$ mannitol, $16 \mathrm{mM}$ Hepes, and $10 \mathrm{mM}$ Tris. Influx of $0.35 \mu \mathrm{M}\left[{ }^{3} \mathrm{H}\right] \mathrm{D}$-glucose was assayed at $20^{\circ} \mathrm{C}$ after the addition of 40 $\mu l$ of an external solution containing $150 \mathrm{mM} \mathrm{NaCl}, 16 \mathrm{mM}$ Hepes, and $10 \mathrm{mM}$ Tris. Insulin was given in amounts sufficient to correct hyperglycemia (Table II). Values represent the mean \pm SEM of from five to seven experiments in each group. 

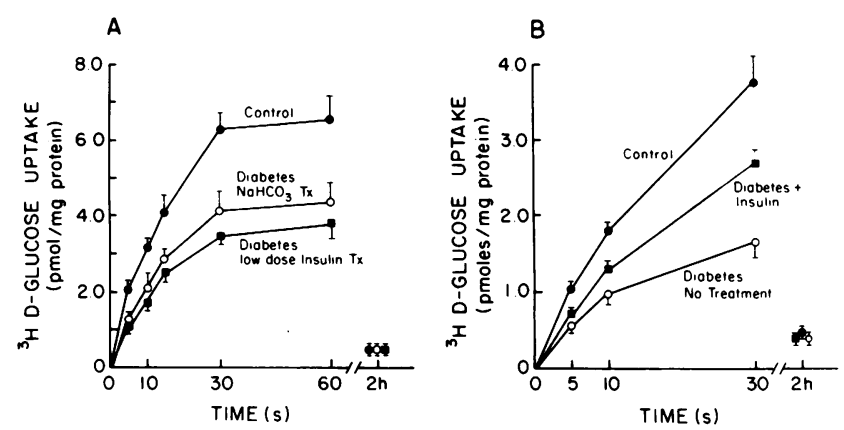

Figure 4. Time course of $\mathrm{Na}^{+}$gradient dependent $\left[{ }^{3} \mathrm{H}\right] \mathrm{D}$-glucose uptake in vesicles from diabetic rats: effect of treatment with $\mathrm{NaHCO}_{3}$ or low dose insulin with continued hyperglycemia. Time course in $(A)$ represents results for streptozotocin-induced diabetes; $(B)$, for BB/W autoimmune diabetes. Vesicles were prepared as described in Fig. 3 and transport studied in the presence of $150 \mathrm{mM} \mathrm{NaCl}$ in the external solution. Values represent mean \pm SEM of three or four experiments in each group.

perature. The effects of temperature on glucose flux are shown in Table VI. Non- $\mathrm{Na}^{+}$-dependent glucose flux, studied in the presence of an inwardly directed gradient of $50 \mathrm{mM} \mathrm{KCl}$, was $0.056 \pm 0.04 \mathrm{pmol} / \mathrm{mg}$ protein per $10 \mathrm{~s}$ at $20^{\circ} \mathrm{C}$ and $0.057 \pm 0.04$ at $37^{\circ} \mathrm{C}(n=3)$. In control animals, $\mathrm{Na}^{+}$-dependent uptake under the nongradient conditions $\left(\mathrm{Na}_{\text {in }}^{+}=\mathrm{Na}_{\text {out }}^{+}\right)$increased from $0.148 \pm 0.01 \mathrm{pmol} / \mathrm{mg}$ protein per $10 \mathrm{~s}$ at $20^{\circ} \mathrm{C}$ to $0.251 \pm 0.011$ at $37^{\circ} \mathrm{C}$. At $37^{\circ} \mathrm{C}$, nongradient $\mathrm{Na}^{+}$-dependent glucose uptake was significantly decreased in vesicles from diabetic animals

Table VI. Effects of Temperature on $\mathrm{Na}^{+}$-dependent Glucose Uptake in Streptozotocin-induced Diabetes

\begin{tabular}{|c|c|c|c|}
\hline \multirow[b]{3}{*}{ Initial condition } & \multicolumn{3}{|c|}{$\left[{ }^{3} \mathrm{H}\right] \mathrm{glucose}$ uptake } \\
\hline & \multicolumn{3}{|c|}{ (pmol/mg protein per $3 \mathrm{~s}$ ) } \\
\hline & $14^{\circ} \mathrm{C}$ & $20^{\circ} \mathrm{C}$ & $37^{\circ} \mathrm{C}$ \\
\hline \multicolumn{4}{|c|}{$\mathrm{Na}_{\text {out }}^{+}=50 \mathrm{mM} ; \mathrm{Na}_{\text {in }}^{+}=0 \mathrm{mM}$} \\
\hline Control & $0.15 \pm 0.01$ & $0.21 \pm 0.03$ & $0.31 \pm 0.02$ \\
\hline \multirow[t]{2}{*}{ Diabetic } & $0.12 \pm 0.03$ & $0.13 \pm 0.04$ & $0.17 \pm 0.02^{*}$ \\
\hline & \multicolumn{3}{|c|}{$\left[{ }^{3} \mathrm{H}\right] \mathrm{glucose}$ uptake } \\
\hline
\end{tabular}

(pmol/mg protein per $10 \mathrm{~s}$ )

\begin{tabular}{llll} 
& $14^{\circ} \mathrm{C}$ & $20^{\circ} \mathrm{C}$ & $37^{\circ} \mathrm{C}$ \\
\hline $\mathrm{Na}_{\text {out }}^{+}=\mathrm{Na}_{\text {in }}^{+}=50 \mathrm{mM}$ & & \\
Control & $0.12 \pm 0.05$ & $0.15 \pm 0.01$ & $0.25 \pm 0.01$ \\
Diabetic & $0.10 \pm 0.01$ & $0.13 \pm 0.02$ & $0.14 \pm 0.04 \ddagger$ \\
& ${ }^{22} \mathrm{Na}^{+}$uptake & & \\
\cline { 2 - 3 } &
\end{tabular}

\begin{tabular}{|c|c|c|c|}
\hline & \multicolumn{3}{|c|}{ (nmol/mg protein per $3 \mathrm{~s}$ ) } \\
\hline & $14^{\circ} \mathrm{C}$ & $20^{\circ} \mathrm{C}$ & $37^{\circ} \mathrm{C}$ \\
\hline \multicolumn{4}{|c|}{$\mathrm{Na}_{\text {out }}^{+}=50 \mathrm{mM} ; \mathrm{Na}_{\text {in }}^{+}=0 \mathrm{mM}$} \\
\hline Control & $5.98 \pm 0.32$ & $8.41 \pm 0.69$ & $10.00 \pm 1.22$ \\
\hline Diabetic & $5.95 \pm 1.47$ & $9.51 \pm 2.65$ & $7.72 \pm 1.94$ \\
\hline
\end{tabular}

* $P<0.05$ compared with control.

$\ddagger P<0.005$ compared with control. $n=3$ for all groups.
$(0.137 \pm 0.038 \mathrm{pmol} / \mathrm{mg}$ protein per $10 \mathrm{~s}$ vs. $0.251 \pm 0.011 \mathrm{in} \mathrm{con}-$ trol; $P<0.05$ ). Also shown in Table VI, $\mathrm{Na}^{+}$gradient stimulated glucose uptake was decreased in diabetics at $37^{\circ} \mathrm{C}(0.172 \pm 0.023$ $\mathrm{pmol} / \mathrm{mg}$ protein per $3 \mathrm{~s}$ vs. $0.311 \pm 0.014$ in control; $P<0.05)$. This effect was not due to greater dissipation of the $\mathrm{Na}^{+}$gradient in diabetic vesicles since $50 \mathrm{mM} \mathrm{Na}{ }^{+}$uptake was not significantly different between the groups. In another set of diabetic animals, rates of $0.1 \mu \mathrm{M} \mathrm{L}$-alanine cotransport studied in vesicles under the condition of $\mathrm{Na}^{+}$preequilibration at $37^{\circ} \mathrm{C}$ were not statistically different from values in control animals $(0.029 \pm 0.003$ $\mathrm{pmol} / \mathrm{mg}$ per $20 \mathrm{~s}$ vs. $0.020 \pm 0.003, n=3$ ).

$\mathrm{Na}^{+}$-dependent glucose uptake was also depressed in vesicles derived from the BB/W rats. As shown in Table VII, initial rates of $\left[{ }^{3} \mathrm{H}\right] \mathrm{D}$-glucose influx were decreased in the diabetic rats $(0.60 \pm 0.07 \mathrm{pmol} / \mathrm{mg}$ protein per $5 \mathrm{~s})$ compared with control $(1.04 \pm 0.06, P<0.05)$. Insulin treatment prevented the metabolic acidosis but not hyperglycemia in these animals (Table III) and as shown in Table VII only partially prevented the fall in glucose transport. These results suggest that the diabetic state per se, not the metabolic acidosis, results in decreased glucose transporter activity. Fig. $4 \mathrm{~B}$ shows the full time course of $\mathrm{Na}^{+}$-dependent glucose uptake into vesicles derived from $\mathrm{BB} / \mathrm{W}$ rats.

Phlorizin binding studies were performed to determine if brush border glucose carrier concentration was altered by diabetes. Previous studies (12) have indicated evidence for a high affinity, $\mathrm{Na}^{+}$-dependent phlorizin binding site in the renal brush border. In the presence of $100 \mathrm{mM} \mathrm{Na}^{+}$, a single high affinity binding site is present in the range of phlorizin concentrations of $0.05-1 \mu \mathrm{M}$. In the present studies, removal of $\mathrm{Na}^{+}$from the incubation medium inhibited $0.02 \mu \mathrm{M}$ phlorizin binding by $85 \%$. There were no differences in this $\mathrm{Na}^{+}$independent phlorizin binding in vesicles from control, untreated streptozotocin induced diabetic and insulin treated diabetic rats.

Scatchard analysis (Fig. 5) of the high affinity binding site revealed no differences in binding sites or affinity for $\mathrm{Na}^{+}$-dependent phlorizin binding in microvillus vesicles from controls, untreated diabetics, and insulin-treated diabetics. There was a numerical but not statistically significant increase in the concentration of sites $\left(R_{0}\right)$ in the untreated diabetics, $176 \pm 6 \mathrm{pmol} /$ mg protein, compared with controls, $138 \pm 13$, while the insulin treated group had an $R_{0}$ of $156 \pm 16$ ( $n=3$ for all groups). Similarly, the binding affinity $\left(K_{\mathrm{D}}\right)$ was $0.76 \pm 0.02 \mu \mathrm{M}$ in the controls, $0.84 \pm 0.08$ in the diabetic, and $0.79 \pm 0.05$ in the insulin-treated animals.

Table VII. BB/W Autoimmune Diabetes $\left[{ }^{3} H\right] D$-Glucose Uptake

\begin{tabular}{llll}
\hline & & \multicolumn{2}{l}{ Diabetes } \\
\cline { 4 - 4 } Time & Control & No treatment & + insulin \\
\hline $\mathrm{NaCl}_{\text {out }}=150 \mathrm{mM} ; \mathrm{NaCl}_{\text {in }}=0 \mathrm{mM}$ & & \\
$5 \mathrm{~s}$ & $1.04 \pm 0.06$ & $0.60 \pm 0.07^{*}$ & $0.75 \pm 0.04^{*}$ \\
$10 \mathrm{~s}$ & $1.84 \pm 0.09$ & $0.97 \pm 0.09^{*}$ & $1.31 \pm 0.09$ \\
$30 \mathrm{~s}$ & $3.78 \pm 0.38$ & $1.69 \pm 0.21^{*}$ & $2.72 \pm 0.21$ \\
$2 \mathrm{~h}$ & $0.48 \pm 0.06$ & $0.44 \pm 0.08$ & $0.53 \pm 0.08$ \\
$(n)$ & $(4)$ & $(3)$ & $(4)$
\end{tabular}

Values given in $\mathrm{pmol} / \mathrm{mg}$ protein. Membrane vesicles were prepared and assays were performed as described in Fig. 3.

* $P<0.05$ compared with control. 


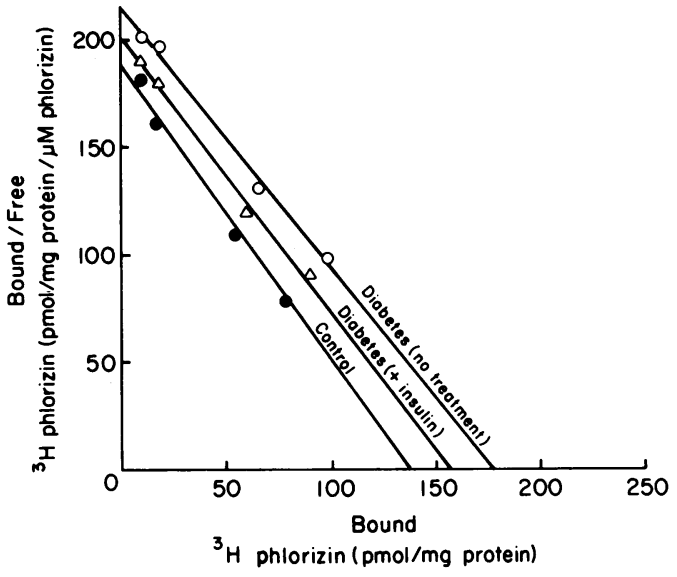

Figure 5. Scatchard transformation of equilibrium ${ }^{3} \mathrm{H}$ phlorizin binding in streptozotocin-induced diabetes. Microvillus membrane vesicles were prepared in $300 \mathrm{mM}$ mannitol, $16 \mathrm{mM}$ Hepes, and $10 \mathrm{mM}$ Tris. Binding assays were performed for $40 \mathrm{~min}$ at $20^{\circ} \mathrm{C}$ after the addition of $10 \mu \mathrm{l}$ of vesicle suspension to $40 \mu \mathrm{l}$ of a solution containing 62.5 $\mathrm{mM} \mathrm{Na}_{2} \mathrm{SO}_{4}, 113 \mathrm{mM}$ mannitol, $16 \mathrm{mM}$ Hepes, $10 \mathrm{mM}$ Tris, and $\left[{ }^{3} \mathrm{H}\right]$ phlorizin to give final concentrations of $0.05-1.0 \mu \mathrm{M}$

$\left[{ }^{3} \mathrm{H}\right]$ phlorizin. Values represent mean \pm SEM for three experiments in each group.

Low affinity $\left[{ }^{3} \mathrm{H}\right]$ phlorizin binding in the range of $5-100 \mu \mathrm{M}$ phlorizin gave an $R_{0}$ of $1,946 \mathrm{pmol} / \mathrm{mg}$ protein and a $K_{\mathrm{D}}$ of 78 $\mu \mathrm{M}$ in controls. In untreated diabetics, $R_{0}$ was $1,816 \mathrm{pmol} / \mathrm{mg}$ protein and $K_{\mathrm{D}}$ was $75 \mu \mathrm{M}$ and in insulin-treated diabetics, $R_{0}$ was $1,773 \mathrm{pmol} / \mathrm{mg}$ protein and $K_{\mathrm{D}}$ was $51 \mu \mathrm{M}$.

\section{Discussion}

Studies in renal microvillus membrane vesicles have shown increases in $\mathrm{Na}^{+} / \mathrm{H}^{+}$exchange activity in response to ammonium chloride-induced metabolic acidosis, glucocorticoid administration, renal ablation, and high protein feeding (19-23). In a preliminary report by El-Seifi et al. (24), $\mathrm{Na}^{+} / \mathrm{H}^{+}$exchange was increased in untreated diabetes. In the present study, untreated streptozotocin-induced diabetic animals demonstrated a significant increase in total and amiloride-sensitive $1 \mathrm{mM}^{22} \mathrm{Na}^{+}$uptake. Insulin treatment prevented the increased $\mathrm{Na}^{+} / \mathrm{H}^{+}$exchange activity seen in the uncontrolled diabetics. The increased exchanger activity occurred without systemic acidemia, but was associated with ketosis and increased net acid excretion, consistent with an increase in endogenous $\mathrm{H}^{+}$production. Bicarbonate treatment of these animals normalized $\mathrm{Na}^{+} / \mathrm{H}^{+}$exchange without correcting the hyperglycemic state. The dose of streptozotocin given to the animals in the present study may not induce ketoacidosis since all functioning islet tissue may not be destroyed (25).

The results in the $\mathrm{BB} / \mathrm{W}$ autoimmune rats provide further evidence that acid-base disturbances rather than insulinopenia per se were responsible for increased $\mathrm{Na}^{+} / \mathrm{H}^{+}$exchange. These animals were severely acidemic when deprived of insulin, and compared with the streptozotocin-treated animals, demonstrated a greater percentage increase in antiporter activity. Correction of the metabolic acidosis normalized $\mathrm{Na}^{+} / \mathrm{H}^{+}$exchange. These results provide the first evidence for increases in $\mathrm{Na}^{+} / \mathrm{H}^{+}$exchange activity secondary to an endogenously induced metabolic acidosis. In metabolic acidosis, increased antiporter activity, by stimulating proton secretion, may be an important adaptation of the nephron to enhance proximal bicarbonate reabsorption $(26,27)$. However, in severe acidosis, the corresponding decrease in filtered substrate may limit overall bicarbonate reabsorption. Although proximal acidification has not been studied in the diabetic model, ammonium chloride acidosis is associated with increased bicarbonate absorption in the proximal tubule perfused in vivo (28). The increased absolute bicarbonate absorptive rate was observed when perfusion rate and luminal concentrations were similar in control and acidotic animals. Although a decrease in intracellular $\mathrm{pH}$ in acidotic animals could explain an increase in $\mathrm{H}^{+}$secretion, the finding is also consistent with the increase in vesicle $\mathrm{Na}^{+} / \mathrm{H}^{+}$exchange noted in that model (19-21). The mediating factors of increased $\mathrm{Na}^{+} / \mathrm{H}^{+}$exchange in untreated diabetes are at present undetermined. Kinsella et al. (20) have shown the importance of glucocorticoids in mediating increased $\mathrm{Na}^{+} / \mathrm{H}^{+}$exchange activity in ammonium chloride-induced acidosis. In untreated diabetes, the corticosteroid levels, as well as those of glucagon and growth hormone, increase, especially in the presence of ketoacidosis (29).

In muscle, insulin has been shown to exert a direct modulating effect on $\mathrm{Na}^{+} / \mathrm{H}^{+}$exchange (30). Although insulin receptors exist on both the luminal and basolateral membranes of the proximal tubule, the role of insulin in regulation of metabolic and transport functions in these cells is unclear (31). In vivo studies in dogs have suggested that acute infusion of insulin may decrease proximal tubule $\mathrm{Na}^{+}$reabsorption (3). Pretreatment of a suspension of proximal tubule fragments with insulin before preparation of microvillus membrane vesicles induced increases in $\mathrm{Na}^{+}-\mathrm{PO}_{4}$ cotransport without change in $\mathrm{Na}^{+}$-glucose cotransport or total $\mathrm{Na}^{+}$uptake (7).

One of the most intriguing possibilities concerning the increase in $\mathrm{Na}^{+} / \mathrm{H}^{+}$activity in early streptozotocin-induced diabetes is the possible relationship between this exchanger and renal hypertrophy. In poorly controlled diabetes significant renal hypertrophy occurs in man and experimental animals (2). The initiating factors and mediators of this hypertrophic response are at present undetermined. Studies in a variety of cultured cells have demonstrated that one of the early responses to mitogenic stimuli involves cytoplasmic alkalinization mediated by $\mathrm{Na}^{+} / \mathrm{H}^{+}$exchange (32). Recent work from our laboratory has suggested a close correlation between the renal hypertrophy induced by contralateral nephrectomy or a high protein diet and increased brush border membrane vesicle $\mathrm{Na}^{+} / \mathrm{H}^{+}$exchange activity (23). In the present studies, increased antiporter activity was noted in the untreated streptozotocin-induced diabetics. In addition to increased acid production rates and hyperglycemia, these animals had significant whole kidney and renal cortical hypertrophy. When the streptozotocin-induced diabetic animals were treated with a long-acting insulin preparation, in an attempt to provide good control of the diabetes, they demonstrated much less renal hypertrophy. In addition, $\mathrm{Na}^{+} / \mathrm{H}^{+}$exchange activity was only minimally elevated above control values. The effect of diabetes on renal mass was difficult to assess in the autoimmune model because of the disparity in body weight in the experimental groups. It remains possible that either systemic or intracellular acidosis is a common feature to states associated with increased $\mathrm{Na}^{+} / \mathrm{H}^{+}$exchange activity and stimulated renal growth. Whether $\mathrm{Na}^{+} / \mathrm{H}^{+}$exchange increases in untreated diabetes simply in response to decreased intracellular $\mathrm{pH}$ of the proximal tubule cell or in response to hormonal or hypertrophic stimuli remains to be determined. 
Studies of glucose transport in intestinal microvillus membrane vesicles from diabetics have indicated increased $\mathrm{Na}^{+}$-glucose cotransport, postulated to be secondary to decreased rates of nonglucose-dependent $\mathrm{Na}^{+}$flux (33). In preliminary reports, Whiting et al. (34) and El-Seifi et al. (24) found evidence for decreased $\mathrm{Na}^{+}$-dependent glucose transport in renal brush border membranes. Since the latter group also demonstrated increased $\mathrm{Na}^{+} / \mathrm{H}^{+}$exchange, it was suggested that the decrease in vesicle glucose transport was secondary to this increase. By contrast, Northrup (35) found no alterations in $\mathrm{Na}^{+}$glucose cotransport although he reported decreased Na-PO${ }_{4}$ cotransport, and Wong et al. (36) found increased $\mathrm{Na}$ glucose cotransport. In the present study, $\mathrm{Na}^{+}$-dependent glucose transport was studied in both the presence and the absence of an inwardly directed $\mathrm{Na}^{+}$gradient. In the presence of an inwardly directed gradient, initial rates of $\left[{ }^{3} \mathrm{H}\right] \mathrm{D}$-glucose were decreased in microvillus vesicles from untreated diabetes compared with controls and were not different from control in membrane vesicles from diabetics given sufficient insulin to control hyperglycemia. Besides an intrinsic decrease in $\mathrm{Na}^{+}$-dependent glucose transport capabilities, these findings could also be attributed to competition by other $\mathrm{Na}^{+}$transport sites for the $\mathrm{Na}^{+}$gradient. Previous studies have demonstrated competition among $\mathrm{Na}^{+}$-glucose, $\mathrm{Na}^{+}$-alanine, and $\mathrm{Na}^{+}$-phosphate cotransport in microvillus vesicles and decreased $\mathrm{Na}^{+}$glucose cotransport when $\mathrm{Na}^{+} / \mathrm{H}^{+}$exchange was increased $(37,38)$. To exclude this possibility, glucose transport was studied in the presence of $\mathrm{Na}^{+}$but under nongradient conditions. Glucose uptake studied at $20^{\circ} \mathrm{C}$ in microvillus vesicles in the absence of a net driving force for $\mathrm{Na}^{+},\left(\mathrm{Na}_{\mathrm{in}}^{+}=\mathrm{Na}_{\text {out }}^{+}\right)$, was numerically but not statistically lower in untreated diabetics than controls. However, in this preequilibrated condition glucose uptake is markedly reduced, although still increased above flux rates in the absence of $\mathrm{Na}^{+}$. Therefore, possible differences in transport rate among groups may not be easily detected. To provide a more sensitive test, transport assays were also performed at $37^{\circ} \mathrm{C}$, a condition expected to increase $\mathrm{Na}^{+}$-dependent glucose uptake. At $37^{\circ} \mathrm{C}$, glucose transport was significantly decreased in diabetic animals, in the presence and absence of the $\mathrm{Na}^{+}$gradient, an effect abolished by insulin treatment. Furthermore, decreased $\mathrm{Na}^{+}$glucose transport in brush border membrane vesicles prepared from diabetic animals treated with $\mathrm{NaHCO}_{3}$, which normalized $\mathrm{Na}^{+}$/ $\mathrm{H}^{+}$exchange, suggests an intrinsic impairment of $\mathrm{Na}^{+}$-glucose transport function. In both streptozotocin-induced and autoimmune diabetics, insulin-treated groups that still manifested marked hyperglycemia and glycosuria continued to exhibit decreased glucose transport, even though $\mathrm{Na}^{+} / \mathrm{H}^{+}$exchange was not different from control values. There was a further decrease in glucose transport in the acidotic $\mathrm{BB} / \mathrm{W}$ rats, who did have increased $\mathrm{Na}^{+}-\mathrm{H}^{+}$exchange rates. In the absence of acidosis $\mathrm{Na}^{+}$ transport was not altered by diabetes. $\mathrm{Na}^{+}-\mathrm{L}$-alanine cotransport was also not significantly different although a small effect cannot be excluded. Other $\mathrm{Na}^{+}$cotransporters not evaluated in the present study may have decreased function in diabetes $(24,35)$.

The significance of decreased $\mathrm{Na}^{+}$-glucose cotransport function in the microvillus membrane to glucose handling in the intact proximal tubule deserves consideration. Net proximal glucose reabsorption, determined by multiple factors, has been shown to increase proportionately with glomerular filtration rate $(\mathrm{GFR})^{1}(39,40)$ and delivery rate $(41)$ and to increase with renal

1. Abbreviations used in this paper: GFR, glomerular filtration rate. hypertrophy (42). In the streptozotocin-treated diabetic rat, net glucose reabsorption has been shown to increase (43), although in that study GFR and filtered glucose load also increased markedly. As a result, the decrease in intrinsic carrier-mediated transport may be more than offset by the increment in filtered glucose load. This is analogous to the situation in metabolic acidosis in which an increase in $\mathrm{Na}^{+} / \mathrm{H}^{+}$exchange and proton secretory capacity is offset by a decrease in filtered bicarbonate load so that absolute bicarbonate reabsorption is diminished (26).

Alterations in GFR in diabetes might induce changes in membrane transport function. However, in a previous report, changes in GFR were not associated with differences in Nadependent glucose transport in microvillus membrane vesicles (23). Severe hyperglycemia and ketoacidosis are associated with a reduced GFR (1). In the rat model of streptozotocin-diabetes, moderate hyperglycemia of the magnitude observed in the present study is associated with an increased GFR (1). It remains possible that changes in GFR may directly regulate carrier activity but it is more likely that glomerular-tubular balance for glucose in the intact proximal nephron is related to effects on glucose delivery and peritubular forces $(39,40)$.

An inverse relationship between ambient glucose concentration and glucose carrier function has been noted previously. Studies in LLC-PK 1 cells, a porcine renal cell line with many characteristics of proximal tubule cells, have shown that the concentration of phlorizin binding sites increases in cells grown in a low glucose medium and decreases when the cells are grown in a high glucose medium (44). In adipose cells, insulin has been shown to exert a direct effect upon glucose transport (8). Insulin administration induces a translocation of glucose transporters to the plasma membrane from an intracytoplasmic pool (45), and insulin seems to regulate the number of cellular glucose transporters available, since streptozotocin-induced diabetes decreases the number of glucose transporters (46). In brain tissue, decreased activity of glucose carriers pertains in the setting of increased net glucose uptake by the cells during hyperglycemia (47). The independent role of insulin or the diabetic state in modifying proximal glucose reabsorption or glucose carrier activity remains to be determined.

To further characterize the adaptive decrease in glucose transport in diabetic animals, we performed phlorizin binding studies. ${ }^{3} \mathrm{H}$ phlorizin binding revealed that there were no significant differences in either concentration of binding sites or substrate affinity among controls, untreated diabetics, and insulin treated diabetics. In fact, there was a numerical but not statistically significant increase in binding sites in untreated diabetics. Therefore, any decreased glucose transport in untreated diabetics cannot be attributed to a decrease in the number of transporting sites available.

Besides a decrease in the number of sites, alteration of the mobility of the transporter in its lipid domain may alter transport activity (48). Phospholipid analysis of plasma membranes isolated from untreated streptozotocin-induced diabetic rats has shown decreased unsaturated fatty acids in phosphotidylcholine and phosphotidylethanolamine, with an increase in linoleic acid and a decrease in arachidonic acid (49). Decreases in the unsaturability index are known to alter membrane fluidity (50). Therefore, an intrinsic change in membrane composition may be involved in decreased rates of $\mathrm{Na}^{+}$gradient dependent glucose uptake noted in untreated diabetics. The alteration in temperature dependence of glucose transport noted in the diabetic brush border membrane vesicles is consistent with a change in mem- 
brane lipid content. Alternatively, changes in the protein composition of the glucose carrier may be secondary to nonenzymatic glycosylation (51).

In conclusion, we have shown increased activity of microvillus membrane $\mathrm{Na}^{+} / \mathrm{H}^{+}$exchange in untreated diabetic rats, related to increases in endogenous $\mathrm{H}^{+}$production. Decreased rates of $\mathrm{Na}^{+}$-glucose cotransport, also associated with the diabetic state, did not require metabolic acidemia or increased acid production but were responsive to insulin treatment. The decreased $\mathrm{Na}^{+}$glucose cotransport is related to decreased functioning of existing carriers rather than a decrease in the number of carriers.

\section{Acknowledgments}

We wish to thank Dr. Arthur Like of University of Massachusetts Medical School, Worcester, MA for supplying us with animals from the BB/W breeding colony. The technical assistance of Robert A. Lufburrow III is gratefully acknowledged.

This work was supported by a grant from the U. S. Public Health Service (AM30410) and the Kroc Foundation. Dr. Seifter is the recipient of a National Institutes of Health New Investigator Research Award (AM31983). Dr. Harris is supported by a National Institutes of Health Institutional National Research Service Award (AM07241).

\section{References}

1. Hostetter, T. H., J. L. Troy, and B. M. Brenner. 1981. Glomerular hemodynamics in experimental diabetes mellitus. Kidney Int. 19:410415.

2. Seyer-Hansen, K. 1983. Renal hypertrophy in experimental diabetes mellitus. Kidney Int. 23:643-646.

3. Hostetter, T. H. 1986. Diabetes mellitus and the kidney. In The Kidney, 3rd ed. B. M. Brenner and F. C. Rector, Jr., editors. W. B. Saunders, Philadelphia. 2:1377-1402.

4. Kamm, D. E., and G. F. Cahill, Jr. 1969. Effects of acid-base status on renal and hepatic gluconeogenesis in diabetes and fasting. Am. J. Physiol. 216:1207-1212.

5. Rostand, S. G., J. B. Watkins, and R. S. Clements, Jr. 1980. The effect of insulin and anti-insulin serum on handling of sodium by the isolated, perfused kidney of the streptozotocin-diabetic rat. Diabetes. 29: 679-685.

6. DeFronzo, R. A., M. Goldberg, and Z. S. Agus. 1976. The effects of glucose and insulin on renal electrolyte transport. J. Clin. Invest. 58: 83-90.

7. Hammerman, M. R., S. Rogers, V. A. Hansen, and J. R. Gavin III. 1984. Insulin stimulates $P_{i}$ transport in brush border vesicles from proximal tubular segments. Am. J. Physiol. 247:E616-E624.

8. Cushman, S. W., and L. J. Wardzala. 1980. Potential mechanism of insulin action on glucose transport in the isolated rat adipose cell. Apparent translocation of intracellular transport systems to the plasma membrane. J. Biol. Chem. 255:4758-4762.

9. Nakhooda, A. F., A. A. Like, C. I. Chappel, F. T. Murray, and E. B. Marliss. 1977. The spontaneously diabetic Wistar rat-metabolic and morphologic studies. Diabetes. 26:100-112.

10. Wilcox, C. S., D. A. Cemerikic, and G. Giebisch. 1982. Differential effects of acute mineralo- and gluco-corticosteroid administration on renal acid elimination. Kidney Int. 21:546-556.

11. Booth, A. G., and A. S. Kenny. 1971. A rapid method for the preparation of microvilli from rabbit kidney. Biochem. J. 142:575-581.

12. Aronson, P. S. 1978. Energy-dependence of phlorizin binding to isolated renal microvillus membranes. J. Membr. Biol. 42:81-98.

13. Rodriguez, R. J., W. C. Hogan, R. N. Hellman, and S. Klahr. 1980. Mechanism of activation of renal $\mathrm{Na}^{+}-\mathrm{K}^{+}$-ATPase in the rat: effects of potassium loading. Am. J. Physiol. 238:F315-F323.

14. Lowry, O. H., N. J. Rosebrough, A. L. Farr, and R. J. Randall.
1951. Protein measurement with folin phenol reagent. J. Biol. Chem. 193:265-275.

15. Bradford, M. M. 1976. A rapid and sensitive method for the quantitation of microgram quantities of protein utilizing the principles of protein-dye binding. Analytical Biochem. 72:248-254.

16. Aronson, P. S., and B. Sacktor. 1975. The $\mathrm{Na}^{+}$-gradient dependent transport of D-glucose in renal brush border membranes. J. Biol. Chem. 250:6032-6039.

17. Kinsella, J. L., and P. S. Aronson. 1980. Properties of the $\mathrm{Na}^{+} /$ $\mathrm{H}^{+}$exchanger in renal microvillus membrane vesicles. Am. J. Physiol. 238:F461-F469.

18. Kinsella, J. L., and P. S. Aronson. 1981. Amiloride inhibition of the $\mathrm{Na}^{+} / \mathrm{H}^{+}$exchanger in renal microvillus membrane vesicles. $A m . J$. Physiol. 241:F374-F379.

19. Cohn, D. E., S. Klahr, and M. R. Hammerman. 1983. Metabolic acidosis and parathyroidectomy increase $\mathrm{Na}^{+} / \mathrm{H}^{+}$exchange in brush border vesicles. Am. J. Physiol. 245:F217-222.

20. Kinsella, J., T. Cudjik, and B. Sacktor. 1984. $\mathrm{Na}^{+} / \mathrm{H}^{+}$exchange activity in renal brush border membrane vesicles in response to metabolic acidosis and the role of glucocorticoids. Proc. Natl. Acad. Sci. USA. 81: 630-634.

21. Tsai, C.-S., H. E. Ives, R. J. Alpern, V. J. Yee, D. G. Warnock, and F. C. Rector, Jr. 1984. Increased Vmax for $\mathrm{Na}^{+} / \mathrm{H}^{+}$antiporter activity in proximal tubule brush border vesicles from rabbits with metabolic acidosis. Am. J. Physiol. 247:F339-F343.

22. Cohn, D. E., K. A. Hruska, S. Klahr, and M. R. Hammerman. 1982. Increased $\mathrm{Na}^{+} / \mathrm{H}^{+}$exchange in brush border vesicles from dogs with renal failure. Am. J. Physiol. 245:F293-F299.

23. Harris, R. C., J. L. Seifter, and B. M. Brenner. 1984. Adaptation of $\mathrm{Na}^{+} / \mathrm{H}^{+}$exchange in renal microvillus membrane vesicles. Role of dietary protein and uninephrectomy. J. Clin. Invest. 74:1979-1987.

24. El-Seifi, S., J. M. Freiberg, and B. Sacktor. 1983. Renal brush border membrane (BBMV) transport in the streptozotocin (SZ) diabetic rat. Fed. Proc. 42:1287. (Abstr.)

25. Grodsky, G. M., C. E. Anderson, E. L. Coleman, J. E. Craighead, G. C. Cerritsen, C. T. Hansen, L. Herberg, C. E. Howard, Jr., A. Lernmark, F. M. Matschinsky, E. Rayfield, W. J. Riley, and A. A. Rossini. 1982. Metabolic and Underlying Causes of Diabetes Mellitus. Diabetes. 31(Suppl. 1):45-53.

26. Cogan, M. G., and R. J. Alpern. 1984. Regulation of proximal bicarbonate reabsorption. Am. J. Physiol. 247:F387-F395.

27. Alpern, R. J., M. G. Cogan, and F. C. Rector, Jr. 1983. Effects of extracellular fluid volume and plasma bicarbonate concentration on proximal acidification. J. Clin. Invest. 71:736-746.

28. Kunau, R. T., Jr., J. I. Hart, and K. A. Walker. 1985. Effect of metabolic acidosis on proximal tubular total $\mathrm{CO}_{2}$ absorption. Am. J. Physiol. 249:F62-68.

29. Porte, D., Jr., and J. B. Halter. 1981. The endocrinal pancreas and diabetes mellitus. In Textbook of Endocrinology. R. H. Williams, editor. W. B. Saunders Co., Philadelphia. 716-843.

30. Moore, R. D. 1983. Effects of insulin upon ion transport. Biochem. Biophys. Acta. 737:1-49.

31. Talor, A., D. S. Emmanouel, and A. I. Katz. 1982. Insulin binding and degradation by luminal and basolateral tubular membranes from rabbit kidney. J. Clin. Invest. 69:1136-1146.

32. Moolenaar, W. H., Y. Yarden, S. W. de Laat, and J. Schlessinger. 1982. Epidermal growth factor induces electrically silent $\mathrm{Na}^{+}$influx in human fibroblasts. J. Biol. Chem. 257:8502-8506.

33. Hopfer, U. 1975. Diabetes mellitus: changes in the transport properties of isolated intestinal microvillus membranes. Proc. Natl. Acad. Sci. USA. 72:2027-2031.

34. Whiting, S. J., W. S. Tse, N. L. Wong, and G. A. Quamme. 1982. Altered renal brush border membrane (BBM) transport in diabetic rats. Fed. Proc. 41:858. (Abstr.)

35. Northrup, T. E. 1982. Increased $\mathrm{Km}$ for phosphate (Pi) transport in renal luminal brush border membranes (LBBM) from diabetic rats. Fed. Proc. 41:859. (Abstr.)

36. Wong, N. L. M., S. J. Whiting, and G. A. Quamme. 1983. Al- 
teration of transport properties in isolated brush border membranes of diabetic rats. Kidney Int. 23:283. (Abstr.)

37. Barrett, P. Q., and P. S. Aronson. 1982. Glucose and alanine inhibition of phosphate transport in renal microvillus membrane vesicles. Am. J. Physiol. 242:F126-F131.

38. Hruska, K. A., S. Klahr, and M. R. Hammerman. 1982. Decreased luminal membrane transport of phosphate in chronic renal failure. Am. J. Physiol. 242:F17-F22.

39. Schultze, R. G., and H. Berger. 1973. The influence of GFR and saline expansion on $\mathrm{Tm}_{\mathrm{G}}$ of the dog kidney. Kidney Int. 3:291-297.

40. Kwong, T.-F., and C. M. Bennett. 1974. Relationship between glomerular filtration rate and maximum tubular reabsorptive rate of glucose. Kidney Int. 5:23-29.

41. Tune, B. M., and M. B. Burg. 1971. Glucose transport by proximal tubules. Am. J. Physiol. 221:580-585.

42. Kramp, R. A., and W. B. Lorentz. 1982. Glucose transport in chronically altered rat nephrons. Am. J. Physiol. 242:F393-F403.

43. Carney, S. L., N. L. Wong, and J. H. Dirks. 1979. Acute effects of streptozotocin diabetes on rat renal function. J. Lab. Clin. Med. 93: 950-960.

44. Moran, A., R. J. Turner, and J. S. Handler. 1983. Regulation of sodium-coupled glucose transport by glucose in a cultured epithelium. J. Biol. Chem. 258:15087-15090.
45. Karnieli, E., M. J. Zarnowski, P. J. Hissin, I. A. Simpson, L. B. Salans, and S. W. Cushman. 1981. Insulin-stimulated translocation of glucose transport systems in the isolated rat adipose cell. Time course, reversal, insulin concentration dependency and relationship to glucose activity. J. Biol. Chem. 256:4772-4777.

46. Karnieli, E., P. J. Hissin, I. A. Simpson, L. B. Salans, and S. W. Cushman. 1981. A possible mechanism of insulin resistance in the rat adipose cell in streptozotocin-induced diabetes mellitus. J. Clin. Invest. 68:811-814.

47. Gjedde, A., and C. Crone. 1981. Blood-brain glucose transfer: repression in chronic hyperglycemia. Science (Wash. DC). 214:456-457.

48. Brasitus, T. A., D. Schachter, and T. G. Mamouncas. 1979. Functional interactions of lipids and proteins in rat intestinal microvillus membranes. Biochemistry. 18:4136-4144.

49. Clark, D. L., F. G. Hamel, and S. F. Queener. 1983. Changes in renal phospholipid fatty acids in diabetes mellitus: correlation with changes in adenylate cyclase activity. Lipids. 18:696-705.

50. DeSmedt, H., and R. Kinne. 1981. Temperature dependence of solute transport and enzyme activities in hog renal brush border membrane vesicles. Biochem. Biophys. Acta. 648:247-253.

51. Brown, M., H. Vlassara, and A. Cerami. 1984. Nonenzymatic glycosylation and the pathogenesis of diabetic complications. Ann. Int. Med. 101:527-537. 